\title{
The importance of SMEs' network partners in consortium bidding for public sector tenders
}

\author{
Helen Reijonen, Jani Saastamoinen and Timo Tammi \\ Faculty of Social Sciences and Business Studies, University of Eastern Finland, \\ Joensuu, Finland
}

\begin{abstract}
Purpose - The aim is to examine the importance small and medium-sized enterprises (SMEs) see in different network partners regarding successful tendering in public procurement, and whether this perception predicts the number of joint bids and wins.

Design/methodology/approach - The data were collected by an electronic questionnaire which was sent to the registered users of the leading electronic platform for public procurement in Finland. The data were analysed with statistical methods.

Findings - The findings suggest that a favourable perception of the importance of horizontal networks in public procurement is associated with a larger number of joint bids and better success in joint bidding. However, the results do not establish a positive correlation between vertical networks and consortium bidding. Research limitations/implications - The data were collected from a single EU country. Since the criteria for bidding consortia may vary between countries, different results might have been achieved from other countries.

Practical implications - SMEs should be encouraged to form bidding consortia and acquire related experience. Policymakers should minimise barriers to consortium bidding, e.g. by offering more information. They should also assess the merits of joint bidding because they rarely encourage SMEs to bid as a consortium. Social implications - Consortium bidding is a way of enhancing SMEs' possibilities to participate in public tender contests, even in large contracts.

Originality/value - While consortium bidding has been recognised to enhance SMEs' possibilities of participating in public procurement, there is limited research into how SMEs' network collaborations relate to bidding as a consortium.
\end{abstract}

Keywords SMEs, Public procurement, Networks, Joint bidding, Bidding consortia

Paper type Research paper

\section{Introduction}

Public procurement is a process in which the public sector buys goods or services with the aim of securing the best value for money (OECD, 2011). Public procurement is recognised as a key economic activity because it represents about $12 \%$ of gross domestic product (GDP) in OECD countries (OECD, 2019a). Every year, the public authorities in the EU spend around 2 trillion euros on public procurement (https:/ec.europa.eu/growth/single-market/ public-procurement_en). To achieve the goal of best value for public money and to enhance the economic vitality of companies that is expected to spill over to a larger society, the ambition is that as many firms as possible could access this voluminous market. However, research shows that small and medium-sized enterprises (SMEs) are underrepresented in public procurement (GHK and Technopolis, 2014) and that their

(C) Helen Reijonen, Jani Saastamoinen and Timo Tammi. Published by Emerald Publishing Limited. This article is published under the Creative Commons Attribution (CC BY 4.0) licence. Anyone may reproduce, distribute, translate and create derivative works of this article (for both commercial and noncommercial purposes), subject to full attribution to the original publication and authors. The full terms of this licence may be seen at http://creativecommons.org/licences/by/4.0/legalcode

This research was funded by the Finnish Agency for Innovation research grant \#40055/14.

SMEs' network partners in consortium bidding

Received 1 April 2021 Revised 2 July 2021 Accepted 27 July 2021 
IJPSM

35,1

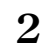

chances of winning public contracts decrease as the value of the contract increases (de Bas et al., 2019). Although they represent about $99 \%$ of all enterprises in the EU, SMEs accounted for only a third of the total contract value during 2011-2017 (de Bas et al., 2019).

Large contract sizes have been identified as a major impediment to SMEs' involvement in public procurement because SMEs often lack sufficient capacity to fulfil large-value contracts (Loader, 2007, 2013; Flynn et al., 2015; Glas and Eßig, 2018). This issue is exacerbated by contract authorities' current trend to aggregate contracts (Loader, 2013). This is problematic from the policy perspective because SMEs contribute significantly to employment and innovation in the economy (The Commission of the European Communities, 2008; Loader, 2013). Consequently, the majority of the OECD countries (29) have developed policies that focus on SMEs' access to public procurement (OECD, 2019a).

Measures to remove this impediment include dividing large contracts into lots (Flynn and Davis, 2015, 2016). However, their effectiveness appears limited: the number of lots does not significantly affect SMEs' bidding success, whereas a more competitive situation in which SMEs can show their flexibility and innovation capacity is positively correlated with success (Glas and EBig, 2018). Consequently, consortium bidding has been advocated as a potential remedy (Flynn and Davis, 2015, 2016). In a bidding consortium, two or more independent suppliers make a joint bid for a procurement contract (Albano et al., 2009). Bidding consortia are not just for SMEs: some countries promote e.g. joint bidding of SMEs with their larger counterparts (OECD, 2019a), which may be especially suitable for larger contracts. Studies suggest that partnering with large firms can be especially beneficial for micro firms (Di Mauro et al., 2020).

From the perspective of regulation, allowing joint bidding has potential benefits as well as hazards. On one hand, a bidding consortium may reduce the efficiency gains from competition because several independent suppliers submit a single bid instead of many (Albano et al., 2009). On the other, pooling suppliers' resources in a joint bid may result in more efficient production capability and efficiency gains (Albano et al., 2009). For instance, a joint bid may allow suppliers to offer an integrated solution that provides performance benefits that would not otherwise be achievable (Thomas, 2015). From the perspective of SMEs, research shows that their indirect participation rate (e.g. as non-leading partners in a consortium) significantly exceeds the rate of direct participation and thus makes partnering an effective form of participation for SMEs (de Bas et al., 2019).

However, there is limited research into how SMEs' network collaborations relate to bidding as a consortium for public sector tenders. For example, we do not know how useful SMEs see different network formations to be regarding joint bidding, or whether these perceptions have anything to do with being active or successful in public procurement. As argued by Loader (2013), "research and action is required to identify how SMEs might effectively form consortia to increase their capacity". Hence, our first aim is to examine how important SMEs find different partners to be regarding successful tendering in public procurement. Second, does this perception of the importance predict SMEs' consortium bidding for public sector tenders, both in terms of the number of bids and number of wins. The data were collected using a surveybased research methodology from the registered users of the leading electronic platform for public procurement in Finland. Finland provides an interesting context because it has the second-highest public spending levels within the OECD countries, and one of its main objectives is to strengthen competitiveness by enhancing SMEs' opportunities to participate in procurement processes (OECD, 2019b). The data were analysed with statistical methods.

This paper contributes to the literature by providing empirical evidence for how SMEs' networks are associated with their reported performance in public sector tendering as a bidding consortium. We examine both vertical (e.g. with suppliers and customers) and horizontal (e.g. with competitors and research institutions) networks (O'Dwyer and Gilmore, 2018). Our results show that SMEs perceive their horizontal network collaborations as 
important in joint bidding. The importance of horizontal networks is positively associated with the reported number of consortium bids and with the reported number of bids won as a consortium. These results suggest that SMEs' costs and barriers associated with forming bidding consortia should be lowered to improve their ability to submit joint bids for public sector tenders.

This paper is organised as follows. Section 2 provides a literature review of bidding consortia and SMEs' networking. Section 3 introduces the data and methodology, and Section 4 reports the results of statistical analyses. Finally, Section 5 concludes with a discussion of the results and their implications.

\section{Literature review and hypothesis development}

\subsection{Bidding consortia}

A bidding consortium is formed when two or more independent firms make a joint bid for a public sector tender. Bidding consortia are regarded as a means for SMEs to participate in public procurement (Flynn and Davis, 2015). As Albano et al. (2008) observe, larger firms may also prefer a bidding consortium in their early-stage bidding to avoid bearing all the beginner's risks on their own, for example. SMEs, as is evident, lack various kinds of economic, technical and administrative resources for bidding individually and are therefore prone to participate through a bidding consortium (Albano et al., 2008).

A bidding consortium is a special case of networking regulated by the legislation on public procurement and the competition law. The key question is whether a bidding consortium increases or decreases competition in public procurement, and whether its consequences are beneficial or harmful to the economy and the end users (Thomas, 2015). In the EU countries, consortium bidding is regulated at the EU level and by national public procurement legislation (Ritter, 2017). In addition, the EU's rules on competition and the national competition law regulate the degree of cooperation allowed for firms (Ritter, 2017). Many, though not all, EU countries have a key condition for allowing bidding as a consortium: if a firm lacks the capacity to participate in public tendering alone, it can form a consortium with other firms that fulfil the same condition (Albano et al., 2009). Some countries have introduced measures where they require winning bidders to subcontract to SMEs (Hoekman and Taş, 2020).

From the SME's perspective, joint tendering is a means to bid for larger contracts than would be possible by submitting a separate bid. It is an established fact that SMEs suffer from resource limitations in public procurement (e.g. Flynn et al., 2015), and for some small firms, resource availability plays the main role in the decision to engage in it (Woldesenbet and Worthington, 2019). SMEs try to surmount the human and financial resource limitations by collaborating in joint bids and establishing partnerships with other industry players (Ancarani et al., 2019). Their motivation to form a bidding consortium is thus related to having access to the resources needed to compete successfully (in general, see Shaw, 2006; Miller et al., 2007) by utilising economies of scale without the diseconomies caused by a large size (Watson, 2007). The other benefits applying to joint bidding include learning, innovation, competitive advantage, value creation, growth and survival (Parker, 2008).

Another issue is risk: bidding consortia provide opportunities to pool risks and, consequently, to reduce the firm's risk of failure (see Watson, 2007). However, cooperation with other firms also involves a risk that partners act opportunistically (Hanna and Walsh, 2008). While the choices between network partners are linked, the participating firms remain independent, make decisions and take actions out of self-interest (Valkokari and Helander, 2007). Firms are therefore required to put great effort into selecting their partners carefully (Hanna and Walsh, 2008). Concerning joint bidding in public procurement, the relevant legislation may influence the magnitude of how much preparation suppliers need to fulfil the 
IJPSM

35,1

requirements for economic and financial standing, technical capacity, professional competence, and if applicable, the binding agreements for fulfilling the contract as a consortium.

\subsection{SME networking}

Networking is an integral part of SMEs' operations and can be considered a way of doing business (Gilmore and Carson, 1999). Small firms usually have informal and formal relationships with their suppliers and customers, from which they fashion a network that "works" for them (Kingsley and Malecki, 2004). Networking is often haphazard and informal: it can be spontaneous and carried out as a reaction to events and opportunities as they occur (Gilmore and Carson, 1999).

However, networking can also be more formal, as in the case of interfirm alliances in which two or more partners cooperate to perform business activities that could include joint manufacturing or sales agreements (BarNir and Smith, 2002). SMEs can seek to cooperate in such discrete groups of firms to achieve benefits that would not be available to them independently (Sherer, 2003). Network ties with customers, suppliers and competitors provide access to advice, resources and problem-solving skills that enable firms to identify and seize opportunities, as well as to gather, share and respond to market intelligence more quickly and with less investment of time and other resources (Boso et al., 2013). These networks are thus beneficial to SMEs through information and cost sharing, technology transfers, improved abilities to outmatch stronger competitors, and access to new markets and resources (BarNir and Smith, 2002).

To gain a competitive advantage, it is important to combine network resources with the SME's internal resources and capabilities (Liu and Yang, 2019). Hence, networking is not merely a means to obtain resources but a mode of being entrepreneurial (Anderson et al., 2010). For example, interfirm networking with other strategic SME network partners is positively related to the entrepreneurial behaviour of the firm, i.e. risk taking, proactiveness and innovativeness (Wincent and Westerberg, 2005). Entrepreneurial orientation, in turn, has been found to enhance SME participation in public procurement (Reijonen et al., 2016).

For a deeper understanding of SMEs' rationale for networking in the case of bidding consortia, we utilise the central ideas from the business economics approach to networking. In general, Håkansson and Snehota (1989) suggest that firms interact with each other continuously. That is, they aim at success by forming and developing informal and formal relationships and networks, and by engaging in strategic networking in a goal-oriented manner (Miller et al., 2007). Companies that form alliances to bid on a public contract create an inter-organisational network in which the leading firm identifies the resources and competences of the network and coordinates it for the purposes of the project (Mamavi et al., 2017). Joint bidding can therefore be regarded as an expression of goal orientation and an endeavour to succeed. It also serves to develop and create relationships with other firms and actors. The fact that an ability to cooperate effectively is a focal skill needed in successful business operations nowadays (Hanna and Walsh, 2008) also applies to joint bidding and should be recognised by regulators and contracting authorities in public procurement. As many markets are in rapid change, networking and strategic collaboration enhances firms' abilities to compete and innovate (Valkokari and Helander, 2007).

\subsection{Vertical and horizontal networks and alliances}

Firm alliances can be categorised as horizontal (e.g. with competitors and research institutions) and vertical (e.g. with suppliers and customers) (O'Dwyer and Gilmore, 2018). Various motivations drive the formation of horizontal and vertical ties, and they can also 
have various impacts (see Lechner et al., 2006). For example, Zeng et al. (2010) found that vertical interfirm collaboration played a more important role for innovation in SMEs than horizontal collaboration with research institutions and government agencies. Based on economic analysis, Parker (2008) argues that formal business networks between entrepreneurs enhance their own performance and bring efficiency and social welfare to the wider economy. However, Lamprinopoulou and Tregear (2011) show that horizontal relationships have little bearing on the marketing performance of SMEs if they are not supported by strong vertical relationships. Robson and Bennett (2000) also find that SMEs' horizontal relations with other firms or collaboration with customers do not exhibit a significant link with performance. Their results show that collaboration with suppliers and private sector consultancies (e.g. lawyers) is beneficial for performance, while government-backed providers of advice have no significant association with it.

Recent empirical evidence on the public procurement of innovations suggests that SMEs' network collaborations are associated with a higher performance in public procurement (Saastamoinen et al., 2018). Edquist et al. (2015) refer to collaboration and interactive learning among suppliers, contracting authorities and various stakeholders as the key dimension in the public procurement of innovations. Furthermore, Uyarra et al. (2017) suggest that more attention should be paid to the fact that procurement of innovations involves interactions between end users, procurers and suppliers, and that these interactions have social and spatial dimensions that is, the exchange of needs, ideas and possible solutions in a "place" and between the stakeholders. Reijonen et al. (2018) suggest that the breadth of collaboration with other suppliers, both vertically and horizontally, seems to improve SMEs' competitive advantage.

In general, SMEs form supply chain partnerships to improve their overall performance and competitive advantage (Rezaei et al., 2015). An upstream vertical alliance with suppliers can bring several benefits for SMEs, including cost and risk reductions, and access to additional production capabilities (see Arend, 2006 for a more extensive list). Collaboration with customers has been seen especially beneficial for creating services and products that are relevant, functional and attractive. Customers can be involved in every stage of the development project, e.g. by providing needs-related knowledge and technical advice, and helping launch new products (Chang and Taylor, 2016). Research indicates that small firms reap greater benefits from such a collaboration than their larger counterparts (Chang and Taylor, 2016). We therefore hypothesise:

H1. Vertical networks are positively associated with (1) submitting consortium bids and (2) winning consortium contracts.

One of the primary goals of forming a strategic horizontal alliance with a competitor is to strengthen their competitiveness against third-party competitors (Perks and Easton, 2000). In competitor collaboration, the partners have similar industrial knowledge and expertise, which can then lead to an improved ability to respond to customers' expressed needs (Ozdemir et al., 2017). Regarding universities, SMEs tend to view collaboration as a means of strengthening market positioning, obtaining new contacts and learning (Bjerregaard, 2009). Collaborating with research institutions with a broad and/or deep knowledge base enhances firms' abilities to respond to customers' latent or future needs (Ozdemir et al., 2017). We hypothesise:

H2. Horizontal networks are positively associated with (1) submitting consortium bids and (2) winning consortium contracts.

\section{Methodology and data}

A survey-based research methodology was used to answer the research question. The survey instrument is based on relevant literature and was also reviewed by leading Finnish public 
IJPSM

35,1

procurement experts to ensure its validity in practice. The questionnaire items used various measurement scales for predictors and dependent variables to reduce common method variance bias (e.g. Chang et al., 2010). The respondents of the survey were firms who were registered users of the main electronic procurement platform in Finland. The platform's market share is almost $90 \%$, with all the major government agencies and the largest municipalities carrying out their procurement through it, which ensures that the data provide comprehensive coverage of public procurement in Finland.

An electronic survey questionnaire was submitted in 2015 to a randomised sample of 10,000 firms registered in an e-procurement platform. Two reminder invitations were sent. A draw for an Apple iPad tablet was held among the survey respondents as an incentive to participate in the survey. The survey resulted in 421 responses. However, concerning the research questions relevant to this study, there were 373 eligible responses, of which 311 respondents answered network-related statements. We further narrowed down the sample by excluding firms that could not be classified as SMEs with respect to the EU criterion of fewer than 250 employees and annual revenue of no more than 50 million euros. The final sample size in our analyses was therefore 273.

The sample represents SMEs which have registered in the "procurement platform". Compared to the size distribution of all SMEs in Finland in 2015, small (10-50 employees) and medium-sized (50-249 employees) firms are overrepresented in the sample (Statistics Finland: https://pxnet2.stat.fi/PXWeb/pxweb/en/StatFin/StatFin__yri__yrti_oik/ statfin_yrti_pxt_11qe.px/table/tableViewLayout1/). Regarding the point of data collection, Finland introduced a law at the beginning of 2017 that e.g. encourages joint bidding by SMEs. However, there is evidence that this new legislation has not significantly increased SMEs' participation and that SMEs still suffer from the lack of capabilities of doing so (Finland - 2019, SBA Fact Sheet). Consequently, it seems there have not been any significant changes in the situation of Finnish SMEs since 2015, and the results are thus still very relevant.

We study how SMEs perceive the importance of vertical and horizontal networks, and how these perceptions are associated with activity and performance in public sector tendering as a bidding consortium. Following previous studies (e.g. Reijonen et al., 2016; Flynn and Davis, 2017; Saastamoinen et al., 2020), we use the number of bids submitted (BIDS) and the number of contracts (CONTRACTS) won as a consortium as the proxies for activity and success in public sector tenders.

We use the methodology developed for research on SME networks and innovation in measuring the perception of the importance of networks in public procurement (see Zeng et al., 2010). Following Arza and Lopez (2011), we measured the SMEs' perception of the importance of networking/collaboration with the following network partners: suppliers, business customers, consumers, local governments or state customers, competitors, consultants/consultancies, private research institutions, public research institutions and universities (see also Official Statistics of Finland, 2018). We therefore asked the respondents to evaluate the importance of potential networking partners on a scale of 1 ("not important") to 5 ("very important") in the question "How important is networking with the following partners with regard to successful tendering in public procurement?"

We use several control variables in the regression analyses. The literature suggests that the firm size (SIZE) measured by the number of employees controls for the firm's resources, activity and performance in public procurement (e.g. Flynn et al., 2015; Reijonen et al., 2016). We also control for firm age (AGE) as measured by years since founding because this has been associated with a firm's activity in public tendering (e.g. Pickernell et al., 2013; Reijonen et al., 2016). Since experience in "regular" public procurement (i.e. bidding as a single entity) may be required to participate in consortium bidding, we use the number of bids submitted in regular public sector tenders (EXPERIENCE) as a proxy for a firm's experience in public 
procurement. Finally, potential industry differences resulting from differences in the public sector's demand for goods and services are also controlled for (Edquist and ZabalaIturriagagoitia, 2012). We keep the healthcare sector (HEALTH) as a reference category, because, according to the European Commission, the public sector is the principal buyer in the industry [1].

The data were analysed using statistical methods with STATA 15 software. Principal component factor analysis (PCFA) was carried out on the statements concerning network partners. Bartlett scores of the resulting extracted components were used as the variables of interest in regression analyses. Since our dependent variables are count variables, we follow Saastamoinen et al. (2020) and use negative binomial regression to investigate how networks are correlated with submitted consortium bids and won consortium contracts [2]. We also carry out a robustness check, using ordinary least squares (OLS) regression.

\section{Results}

\subsection{Factor analysis of networks}

The results of PCFA are reported in Table 1. The solution yields two principal component factors. We label them "vertical networks" consisting of the firm's upstream (suppliers) or downstream (business customers, consumers and local government or state) partners and "horizontal networks" consisting of the firm's competitors, consultancy services, public and private research institutions, and universities or other higher education institutions (e.g. polytechnic colleges). Both factors exhibit good internal consistency for exploratory work with Cronbach's alphas of 0.77 and 0.83. Bartlett scores of these factors (VERTICAL for vertical networks; HORIZONTAL for horizontal networks) with the mean at zero and a standard deviation of one are used as independent variables in regression analyses. Average responses suggest that the respondents perceive "vertical networks" as more important than "horizontal networks" because the means of the former (the latter) are above (below) 3 and statistically significant indicating above (below) average perceived importance.

\begin{tabular}{|c|c|c|c|c|c|c|}
\hline Variable & Obs & Mean & $\begin{array}{l}\text { Std. } \\
\text { Dev. }\end{array}$ & $t$-statistic ${ }^{\mathrm{x}}$ & $\begin{array}{l}\text { Vertical } \\
\text { network }\end{array}$ & $\begin{array}{c}\text { Horizontal } \\
\text { network }\end{array}$ \\
\hline Suppliers & 278 & & & $2.32 * *$ & 0.723 & \\
\hline Business customers & 278 & & & $8.07 * * *$ & 0.820 & \\
\hline Consumers & 278 & & & $10.54 * * *$ & 0.852 & \\
\hline $\begin{array}{l}\text { Local government or state } \\
\text { customers }\end{array}$ & 278 & & & $7.21 * * *$ & 0.595 & \\
\hline Competitors & 278 & & & $-2.97 * * *$ & & 0.542 \\
\hline Consultants/consultancies & 278 & & & $-5.73^{* * * *}$ & & 0.617 \\
\hline Private research institutions & 278 & & & $-10.82 * * *$ & & 0.871 \\
\hline Public research institutions & 278 & & & $-8.30 * * *$ & & 0.886 \\
\hline $\begin{array}{l}\text { Universities and other higher } \\
\text { education institutions }\end{array}$ & 278 & & & $-5.70 * * *$ & & 0.822 \\
\hline$\%$ of variance explained & & & & & 27.3 & 33.8 \\
\hline Cronbach's alpha & & & & & 0.77 & 0.83 \\
\hline Lambda & & & & & 1.41 & 4.05 \\
\hline
\end{tabular}

Note(s): ${ }^{\mathrm{x}} \mathrm{A} t$-test statistic for the mean value of an item being equal to 3 (the midpoint of the measurement scale). Statistical significance: $* * p$-value $<0.05 ; * * *$-value $<0.01$. Oblique rotation applied in factor analysis.

Bartlett's test of sphericity: 1197.10 ( $p$-value $<0.001$ ). KMO $=0.801$

SMEs' network partners in consortium bidding
Principal component factor analysis of network collaborations 
IJPSM

35,1

8

\subsection{Descriptive statistics}

Table 2 reports the descriptive statistics of the variables used in regression analyses. The average number of consortium bids over the last five years was 3.82. In comparison, the mean of "regular" procurement bids was 35.69. The success rate was considerably lower because the mean number of contracts won as a consortium was 1.13. The firm size variable indicates that the average firm had 16 employees. The average firm had been in business for 18 years. The correlations matrix in Table 2 shows that correlations between the explanatory variables were rather low. This suggests that multicollinearity may not have been an issue in regression analyses (we further confirm this by computing variance inflation factors, which were also well below 5$)$.

\subsection{Results of negative binomial regressions}

The results of negative binomial regressions are reported in Table 3 . Since the dependent variables exhibit variance above the mean (Table 2), negative binomial regression is a valid estimation technique. The log-likelihood ratio test of alpha is also statistically significant, which indicates that the dispersion of the dependent variable is large and, consequently, a negative binomial regression model can be used.

The left-hand panel of Table 3 reports the estimated coefficients on bids submitted as a consortium. The firms that regard horizontal networks as important partners in public procurement submit more consortium bids. H2a is therefore supported. However, the importance of vertical networks is not a statistically significant predictor of tendering activity. H1a is therefore not supported. We also find that experience in "regular" public procurement and large firms are positively associated with consortium bidding. Furthermore, industrial and trade sectors are positively correlated with consortium bidding, whereas the construction sector is a negative predictor of consortium bids.

The right-hand panel of Table 3 reports the estimated coefficients on the number of public sector contracts secured as a consortium. Again, we find that a positive perception of horizontal network partners is a predictor of successful consortium bids. Hence, H2b is supported. However, vertical networks are not statistically significant, and H1b is therefore not supported. Regarding the control variables, older firms are negatively associated with the contracts won. Experience in "regular" public procurement also predicts success in consortium bids. With respect to sectors, construction firms are negatively associated with winning consortium contracts.

\subsection{Robustness check}

We also estimated the regression models using OLS with log-transformed dependent variables. The results are qualitatively similar to those reported in Table 3. Hence, the results are robust to alternative estimation methods. We also estimated a generalised structural equations model to check whether regular procurement experience is a driver of SME networking (and vice versa), which in turn predicts consortium bidding. Since neither model yields statistically significant mediation effects, we conclude that the perception of SME networks is correlated with consortium bidding.

\section{Conclusion}

\subsection{Discussion}

Supplier collaboration as bidding consortia has been advocated to encourage and facilitate SMEs' participation in public sector tenders. However, most research into bidding consortia in public procurement has adopted the view of informing and advising regulators on promoting competition and preventing collusion and anti-competitive practices in joint bidding (Thomas, 2015). The present work contributes to the literature by investigating SMEs' networking in consortium bidding, using a survey of Finnish suppliers. 


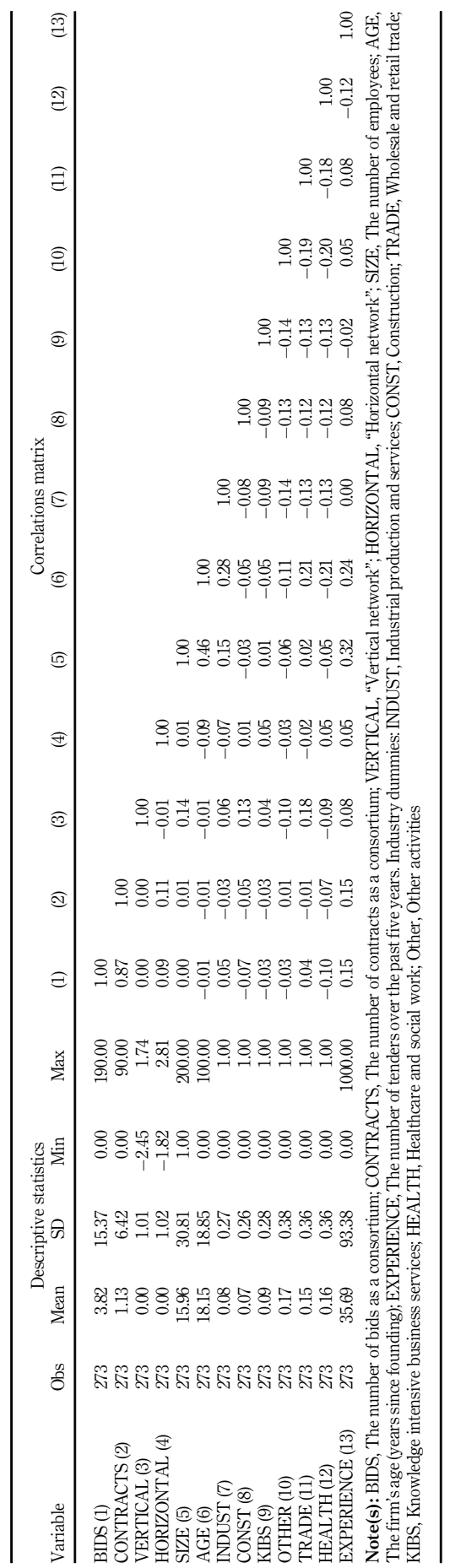

SMEs' network partners in consortium bidding

Table 2. Descriptive statistics and the correlations matrix 


\begin{tabular}{|c|c|c|c|c|c|c|c|}
\hline \multirow{2}{*}{$\begin{array}{l}\text { IJPSM } \\
35,1\end{array}$} & \multirow[b]{2}{*}{ Dep. Var } & & & & & & \\
\hline & & Coef & BIDS & $p$-value & \multicolumn{2}{|r|}{$\begin{array}{l}\text { CONTRACTS } \\
\text { Std. Err }\end{array}$} & $p$-value \\
\hline \multirow{6}{*}{10} & VERTICAL & -0.062 & 0.181 & 0.733 & 0.069 & 0.227 & 0.762 \\
\hline & HORIZONTAL & 0.340 ** & 0.134 & 0.011 & $0.373 * *$ & 0.163 & 0.023 \\
\hline & Ln(SIZE) & -0.110 & 0.142 & 0.437 & 0.030 & 0.192 & 0.875 \\
\hline & $\operatorname{Ln}(\mathrm{AGE})$ & -0.016 & 0.200 & 0.934 & -0.241 & 0.249 & 0.334 \\
\hline & EXPERIENCE & $0.463 * * *$ & 0.096 & 0.000 & $0.555 * * *$ & 0.121 & 0.000 \\
\hline & CONSTRUCTION & $-2.382 * * *$ & 0.724 & 0.001 & $-3.355^{* * * *}$ & 1.251 & 0.007 \\
\hline \multirow{9}{*}{$\begin{array}{l}\text { Table } 3 \text {. } \\
\text { Negative binomial } \\
\text { regression estimates }\end{array}$} & INDUSTRIAL & $2.168 * * *$ & 0.650 & 0.001 & -0.313 & 0.733 & 0.669 \\
\hline & KIBS & -0.094 & 0.543 & 0.863 & -0.970 & 0.729 & 0.183 \\
\hline & TRADE & $1.253 * * *$ & 0.479 & 0.009 & 0.790 & 0.618 & 0.201 \\
\hline & OTHER & -0.053 & 0.417 & 0.899 & 0.572 & 0.525 & 0.276 \\
\hline & CONSTANT & -0.116 & 0.522 & 0.823 & $-1.137^{*}$ & 0.609 & 0.062 \\
\hline & Log likelihood & $46-2$ & -487.55 & 0000 & 403 & -261.01 & 0.000 \\
\hline & Pseudo $R^{2}$ & 40.07 & 0.046 & .000 & & 0.072 & .000 \\
\hline & Obs & & 273 & & & 273 & \\
\hline & \multicolumn{7}{|c|}{ Note(s): $* * * p$-value $<0.01 ; * * p$-value $<0.05 ; * p$-value $<0.1$} \\
\hline
\end{tabular}

Our findings suggest that a favourable perception of the importance of horizontal networks in public procurement is associated with a larger number of joint bids. Our results also indicate that a positive perception of horizontal network collaboration is a predictor of success in joint bidding. This is consistent with the finding presented in various streams of research on SMEs that alliance between rival SMEs may be used to achieve economies of scale and scope (e.g. Gomes-Casseres, 1999; Gnyawali and Park, 2009). In public procurement, consortia between competing firms can be regarded as a form of formal coopetition where in addition to achieving economies of scale the aim is to reduce transaction costs (Godlewska, 2018).

However, our empirical analysis does not establish a positive correlation between vertical networks and consortium bidding. This is somewhat inconsistent with the SME literature, in which collaboration with customers and suppliers are highlighted as important in terms of information exchange and firm performance (e.g. Robson and Bennet, 2000). In the context of the public procurement of innovations, both horizontal networks (e.g. with competitors) and vertical networks (e.g. with public sector customers) are seen as beneficial (Reijonen et al., 2018). The apparent lack of significance of the vertical networks in this study may lie in the fact that while the interaction needed to develop innovative public products or services is quite intense (see e.g. Brogaard, 2021), the regular public sector purchasing is often characterised by the arm's length interaction between public sector customers and suppliers.

Regarding the background variables in the regression models, our findings indicate that experience in "regular" public procurement, that is, bidding as a single entity, predicts joint bidding and success in the number of contracts awarded. This finding can be interpreted as a manifestation of an accumulated information advantage (Albano et al., 2008): winning a contract and fulfilling it generates learning and information, which is then utilisable in other forms of tendering and increases the probability of winning future bidding contests.

\subsection{Implications, limitations and future research}

The results presented in this paper lend themselves to several policy implications. Although our results confirm prior research showing that consortium bidding is beneficial to SME participation in public procurement, studies have also shown that there are two notable 
hindrances to its deployment: first, SMEs' reluctance to form consortia (Loader and Norton, 2015) and public buyers' low compliance in applying consortium bids (Flynn and Davis, 2016).

SMEs' reluctance to form consortia is partly due to a lack of experience, and they therefore need support in the form of advice and facilitation (Loader, 2005). The public authorities should consequently ensure that information on large tenders is abundant and easily accessible for SMEs. In addition, the contracting authorities should inform firms of forthcoming large tenders well in advance so that SMEs have time to form consortia. The barriers to accumulating experience in forming bidding consortia and joint bidding should be made as low as possible. Micro firms may be encouraged by research findings that show them to have a higher frequency of success than their larger counterparts, partly due to participating in public procurement as subcontractors of or in partnership with larger firms (Di Mauro et al., 2020).

Regarding public buyers' low compliance in applying consortium bids, the contracting authorities should assess the merits of joint bidding because collaboration between rival SMEs increases their joint ability to compete in the marketplace (Gnyawali and Park, 2009). It seems that public buyers comply less with measures over which they can exert discretion that are less visible in terms of implementation and that are connected with higher transaction costs (Flynn and Davis, 2016). This is the case with consortium bids. Policymakers should therefore review the regulations and practices of public procurement and seek ways to minimise the existing impediments to consortium bidding and networking in public procurement. Studies have shown that regulations and policies are significant promoters of SME-friendly practices, but they must be backed up by top managers' commitment and communication (Liu et al., 2020). It is therefore focal to ensure that all public buyers are fully aware and up-to-date with SME-friendly policies, including consortium bids, and that they also realise the importance of SMEs' access to public procurement from the perspective of the competitive benefits they bring to it (Flynn and Davis, 2016).

Sometimes the public sector authorities and small firm suppliers do not seem to agree on the use of SME-friendly initiatives. A study carried out in Ireland showed that while suppliers stated that encouragement for joint bids by two or more smaller suppliers was the least implemented initiative, almost a third of public sector respondents claimed to put it into practice (Flynn et al., 2013). To encourage the use further, new developments are brought to joint bidding. Although large firms are usually selected as host companies in bidding consortia, there are programmes to promote SME growth in the US where SMEs sign the contracts and then subcontract some to large firms (Park et al., 2021).

As with all research, this study has some limitations, which also suggests prospects for future research. The data were collected from a single EU country (Finland), a highly developed Nordic country where - pertaining to joint bidding in public procurement - the "regulatory dimension" in public procurement is characterised by EU and national legislation. Since the criteria for "legal" bidding consortia may vary between countries (including within the EU), different results may have been obtained from other countries. Moreover, the key predictor in this study is the perceived importance of network collaboration (either horizontal or vertical), which is not directly related to the actual network resources SMEs have. In addition, perceptions concerning network partners may be cultural because Finnish SMEs may see networks as business relationships and repeatedly collaborate with other stakeholders, but in some other jurisdictions, networks may be regarded as personal connections which make them vulnerable to misconceptions (Ottesen et al., 2004; McGrath and O'Toole, 2010). It is also possible that contract types (e.g. a contract requiring innovation as opposed to a contract requiring large-scale production) may be correlated with the network types required for a consortium bid. However, the measure used for contracts in this study does not distinguish between different contract types and may thus limit the generalisability of the results.

As directions for future research, actual network resources could be added to the analysis. Moreover, using real-world data instead of self-reported measures could improve reliability. 
IJPSM

35,1

Regarding our results, our current data cannot explain why horizontal networking is related to participation in bidding consortia and performance, but vertical networking is not. Further research could therefore be undertaken to explore this issue. Future research could also explore whether different contract types require specific network configurations. Finally, it would be interesting to study further the reasoning behind SMEs' reluctance to form consortia and the public sector's reluctance to apply joint bidding.

Notes

1. https://ec.europa.eu/growth/single-market/public-procurement_en

2. A statistical test on model dispersion indicated that negative binomial regression is more appropriate than Poisson regression.

\section{References}

Albano, G., Dini, F. and Zampino, R. (2008), "Suppliers' behavior in competitive tendering: evidence from the Italian Ministry of Economy and Finance's acquisitions of it services", 3rd International Public Procurement Conference Proceedings, pp. 667-705.

Albano, G.L., Spagnalo, G. and Zanza, M. (2009), "Regulating joint bidding in public procurement", Journal of Competition Law and Economics, Vol. 5 No. 2, pp. 335-360.

Ancarani, A., Di Mauro, C., Hartley, T. and Tátrai, T. (2019), "A comparative analysis of SME friendly public procurement: results from Canada, Hungary and Italy", International Journal of Public Administration, Vol. 42 No. 13, pp. 1106-1121.

Anderson, A.R., Dodd, S.D. and Jack, S. (2010), "Network practices and entrepreneurial growth", Scandinavian Journal of Management, Vol. 26 No. 2, pp. 121-133.

Arend, R. (2006), "SME-supplier alliance activity in manufacturing: contingent benefits and perceptions", Strategic Management Journal, Vol. 27, pp. 741-763.

Arza, V. and López, A. (2011), "Firms' linkages with public research organisations in Argentina: drivers, perceptions and behaviours", Technovation, Vol. 31 No. 8, pp. 384-400.

BarNir, A. and Smith, K.A. (2002), "Interfirm alliances in the small business: the role of social networks", Journal of Small Business Management, Vol. 40 No. 3, pp. 219-232.

Bjerregaard, T. (2009), "Universities-industry collaboration strategies: a micro-level perspective", European Journal of Innovation Management, Vol. 12 No. 2, pp. 161-176.

Boso, N., Story, V.M. and Cadogan, J.W. (2013), "Entrepreneurial orientation, market orientation, network ties, and performance: study of entrepreneurial firms in developing economy", Journal of Business Venturing, Vol. 28, pp. 708-727.

Brogaard, L. (2021), "Innovative outcomes in public-private innovation partnerships: a systematic review of empirical evidence and current challenges", Public Management Review, Vol. 23 No. 1, pp. 135-157.

Chang, W. and Taylor, S. (2016), "The effectiveness of customer participation in new product development: a meta-analysis", Journal of Marketing, Vol. 80 No. 1, pp. 47-64.

Chang, S.-J., Witteloostuijn, A.V. and Eden, L. (2010), "From the Editors: common method variance in international business research”, Journal of International Business Studies, Vol. 41, pp. 178-184.

de Bas, P., Hausemer, P., Kruger, T., Rabuel, L., de Vet, J.M. and Vincze, M. (2019), "Analysis of the SMEs' participation in public procurement and the measures to support it - 697/PP/GRO/IMA/ 18/1131/10226”, Final Report, Directorate-General for Internal Market, Industry, Entrepreneurship and SMEs, European Commission.

Di Mauro, C., Ancarani, A. and Hartley, T. (2020), "Unravelling SMEs' participation and success in public procurement”, Journal of Public Procurement, Vol. 20 No. 4, pp. 377-401. 
Edquist, C. and Zabala-Iturriagagoitia, J.M. (2012), "Public Procurement for Innovation as missionoriented innovation policy", Research Policy, Vol. 41, pp. 1757-1769.

Edquist, C., Vonortas, N.S. and Zabala-Iturriagagoitia, J.M. (2015), "Introduction", in Edquist, C., Vonortas, N., Zabala-Iturriagagoitia, J. and Edler, J. (Eds), Public Procurement for Innovation, Edward Elgar, Cheltenham, pp. 1-31.

SMEs' network partners in consortium bidding

Finland (2019), "SBA fact Sheet", available at: https://ec.europa.eu/docsroom/documents/38662/ attachments/10/translations/en/renditions/pdf.

Flynn, A. and Davis, P. (2015), "The rhetoric and reality of SME-friendly procurement", Public Money and Management, Vol. 35 No. 2, pp. 111-118.

Flynn, A. and Davis, P. (2016), "The policy-practice divide and SME-friendly public procurement", Environment and Planning C: Government and Policy, Vol. 34, pp. 559-578.

Flynn, A. and Davis, P. (2017), "Investigating the effect of tendering capabilities on SME activity and performance in public contract competitions", International Small Business Journal, Vol. 35 No. 4, pp. 449-469.

Flynn, A., Davis, P., McKevitt, D. and McEvoy, E. (2013), "Mapping public procurement in Ireland", Public Procurement Law Review, Vol. 2, pp. 74-95.

Flynn, A., McKevitt, D. and Davis, P. (2015), “The impact of size on small and medium-sized enterprise public sector tendering", International Small Business Journal, Vol. 33 No. 4, pp. 443-461.

GHK and Technopolis (2014), "Evaluation of SMEs' access to public procurement markets in the EU", Final Report, DG Enterprise and Industry of the European Commission, available at: ec.europa. eu/DocsRoom/documents/2153/attachments/1/translations/en/...pdf.

Gilmore, A. and Carson, D. (1999), "Entrepreneurial marketing by networking”, New England Journal of Entrepreneurship, Vol. 2 No. 2, pp. 31-38.

Glas, A.H. and Eßig, M. (2018), "Factors that influence the success of small and medium-sized suppliers in public procurement: evidence from centralized agency in Germany", Supply Chain Management: An International Journal, Vol. 23 No. 1, pp. 65-78.

Gnyawali, D.R. and Park, B. (2009), "Co-opetition and technological innovation in small and mediumsized enterprises: a multilevel conceptual model", Journal of Small Business Management, Vol. 47 No. 3, pp. 308-330.

Godlewska, M. (2018), "Public procurement and mechanisms of competition. Example of bidding consortium”, Kwartalnik Nauk o Przedsięiorstwie, Vol. 46, pp. 51-60, doi: 10.5604/01.3001. 0012.0988.

Gomes-Casseres, B. (1999), “Alliance strategies of small firms”, in Ács, Z. and Yeung, B. (Eds), Small and Medium-Sized Enterprises in the Global Economy, University of Michigan Press, pp. 67-87.

Håkansson, H. and Snehota, I. (1989), "No business is an island: the network concept of business strategy", Scandinavian Journal of Management, Vol. 5 No. 3, pp. 187-200.

Hanna, V. and Walsh, K. (2008), "Interfirm cooperation among small manufacturing firms", International Small Business Journal, Vol. 26 No. 3, pp. 299-321.

Hoekman, B. and Taş, B.K.O. (2020), "Procurement policy and SME participation in public purchasing", Small Business Economics. doi: 10.1007/s11187-020-00414-z.

Kingsley, G. and Malecki, E.J. (2004), "Networking for competitiveness”, Small Business Economics, Vol. 23 No. 1, pp. 71-84.

Lamprinopoulou, C. and Tregear, A. (2011), "Inter-firm relations in SME clusters and the link to marketing performance", Journal of Business and Industrial Marketing, Vol. 26 No. 6, pp. 421-429.

Lechner, C., Dowling, M. and Welpe, I. (2006), "Firm networks and firm development: the role of the relational mix", Journal of Business Venturing, Vol. 21 No. 4, pp. 514-540.

Liu, H. and Yang, H. (2019), "Managing network resource and organizational capabilities to create competitive advantage for SMEs in a volatile environment", Journal of Small Business Management, Vol. 57 No. S2, pp. 155-171. 
IJPSM

35,1

Liu, J., Liu, Y., Ma, Y. and Xie, G. (2020), "Promoting SMEs friendly public procurement (SFPP) practice in developing country: the regulation and policy motivator and beyond", The Social Science Journal. doi: 10.1080/03623319.2020.1799180.

Loader, K. (2005), "Supporting SMEs through government purchasing activity", The International Journal of Entrepreneurship and Innovation, Vol. 6 No. 1, pp. 17-26.

Loader, K. (2007), "The challenge of competitive procurement: value for money versus small business support", Public Money and Management, Vol. 27 No. 5, pp. 307-314.

Loader, K. (2013), "Is public procurement a successful small business support policy? A review of the evidence", Environment and Planning C: Government and Policy, Vol. 31, pp. 39-55.

Loader, K. and Norton, S. (2015), "SME access to public procurement: an analysis of the experiences of SMEs supplying the publicly funded UK heritage sector", Journal of Purchasing and Supply Management, Vol. 21 No. 4, pp. 241-250.

Mamavi, O., Meier, O. and Zerbib, R. (2017), "How do strategic networks influence awarding contract? Evidence from French public procurement”, International Journal of Public Sector Management, Vol. 30 No. 4, pp. 357-369.

McGrath, H. and O'Toole, T. (2010), “The potential and challenge of the network realization capability for SMEs in Ireland and Finland", Journal of Business Marketing Management, Vol. 4, pp. 27-49.

Miller, N.J., Besser, T. and Malshe, A. (2007), "Strategic networking among small businesses in small US Communities”, International Small Business Journal, Vol. 25 No. 6, pp. 631-665.

OECD (2011), “Competition and procurement. Key findings", Competition Committee, available at: https://www.oecd.org/regreform/sectors/48315205.pdf.

OECD (2019a), Government at a Glance 2019, OECD Publishing, Paris, doi: 10.1787/8ccf5c38-en.

OECD (2019b), "Productivity in public procurement. A case study of Finland: measuring the efficiency and effectiveness of public procurement", available at: https://www.oecd.org/gov/publicprocurement/publications/productivity-public-procurement.pdf.

Official Statistics of Finland (2018), Innovation, [e-publication], ISSN=1797-4399, 2016, Statistics Finland, Helsinki, available at: http://www.stat.fi/til/inn/2016/inn_2016_2018-04-12_tie_001_en. html (accessed 15 April 2020).

Ottesen, G., Foss, L. and Grønhaug, K. (2004), "Exploring the accuracy of SME managers' network perceptions", European Journal of Marketing, Vol. 38 Nos 5/6, pp. 593-607.

Ozdemir, S., Kandemir, D. and Eng, T. (2017), "The role of horizontal and vertical new product alliances in responsive and proactive market orientations and performance of industrial manufacturing firms”, Industrial Marketing Management, Vol. 64, pp. 25-35.

O'Dwyer, M. and Gilmore, A. (2018), "Value and alliance capability and the formation of strategic alliances in SMEs: the impact of customer orientation and resource optimisation", Journal of Business Research, Vol. 87, pp. 56-68.

Park, D., Jo, J. and Ryu, D. (2021), "Incentive contracts for sustainable growth of small or medium-sized enterprise", Sustainability, Vol. 13 No. 9, p. 4964.

Parker, S.C. (2008), "The economics of formal business networks", Journal of Business Venturing, Vol. 23 No. 6, pp. 627-640.

Perks, H. and Easton, G. (2000), "Strategic alliances: partner as customer", Industrial Marketing Management, Vol. 29 No. 4, pp. 327-338.

Pickernell, D., Senyard, J., Jones, P., Packham, G. and Ramsey, E. (2013), "New and young firms: entrepreneurship policy and the role of government - evidence from the Federation of small businesses survey",Journal of Small Business and Enterprise Development, Vol.20 No. 2, pp. 358-382.

Reijonen, H., Tammi, T. and Saastamoinen, J. (2016), "SMEs and public sector procurement: does entrepreneurial orientation make a difference?”, International Small Business Journal, Vol. 34 No. 4, pp. 468-486. 
Reijonen, H., Saastamoinen, J. and Tammi, T. (2018), "Does collaboration with public and private sector actors in public procurement of innovations improve SME competitiveness?", in Gråsjö, U., Karlsson, C. and Bernhard, I. (Eds), Geography, Open Innovation and Entrepreneurship, Edward Elgar.

Rezaei, J., Ortt, R. and Trott, P. (2015), "How SMEs can benefit from supply chain partnerships", International Journal of Production Research, Vol. 53 No. 5, pp. 1527-1543.

Ritter, C. (2017), "Joint tendering under EU competition law", available at: https://papers.ssrn.com/ sol3/papers.cfm?abstract_id=2909572anddownload=yes.

SMEs' network partners in consortium bidding

Robson, P.J.A. and Bennett, R.J. (2000), "SME growth: the relationship with business advice and external collaboration”, Small Business Economics, Vol. 15 No. 3, pp. 193-208.

Saastamoinen, J., Tammi, T. and Reijonen, H. (2018), "Should SMEs pursue public procurement to improve innovative performance?”, Technovation, Vol. 69, pp. 2-14.

Saastamoinen, J., Reijonen, H. and Tammi, T. (2020), "SMEs' market orientation toward public sector customers in public procurement", International Journal of Public Sector Management, Vol. 34 No. 1, pp. 1-16.

Shaw, E. (2006), "Small firm networking. An insight into contents and motivating factors", International Small Business Journal, Vol. 24 No. 1, pp. 5-29.

Sherer, S.A. (2003), "Critical success factors for manufacturing networks as perceived by network coordinators", Journal of Small Business Management, Vol. 41 No. 4, pp. 325-345.

The Commission of the European Communities (2008), "European code of best practices facilitating access by SMEs to public procurement contracts, commission staff working document", available at: http://ec.europa.eu/internal_market/publicprocurement/docs/sme_code_of_best_ practices_en.pdf.

Thomas, C. (2015), "Two bids of not to bid? An exploration of the legality of joint bidding and subcontracting under EU competition law", Journal of European Competition Law and Practice, Vol. 6 No. 9, pp. 629-638.

Uyarra, E., Flanagan, K. and Magro, E. (2017), "Anchoring the innovation impacts of public procurement to place: the role of conversations", Environment and Planning C: Politics and Space, Vol. 35 No. 5, pp. 828-848.

Valkokari, K. and Helander, N. (2007), "Knowledge management in different types of strategic SME networks", Management Research News, Vol. 30 No. 8, pp. 597-608.

Watson, J. (2007), "Modeling the relationship between networking and firm performance", Journal of Business Venturing, Vol. 22 No. 6, pp. 852-874.

Wincent, J. and Westerberg, M. (2005), "Personal traits of CEOs, inter-firm networking and entrepreneurship in their firms: investigating strategic SME network participants", Journal of Developmental Entrepreneurship, Vol. 10 No. 3, pp. 271-284.

Woldesenbet, K. and Worthington, I. (2019), "Public procurement and small businesses: estranged or engaged?”, Journal of Small Business Management, Vol. 57 No. 4, pp. 1661-1675.

Zeng, S.X., Xie, X.M. and Tam, C.M. (2010), "Relationship between cooperation networks and innovation performance of SMEs", Technovation, Vol. 30 No. 3, pp. 181-194.

\section{Corresponding author}

Helen Reijonen can be contacted at: helen.reijonen@uef.fi

For instructions on how to order reprints of this article, please visit our website:

www.emeraldgrouppublishing.com/licensing/reprints.htm

Or contact us for further details: permissions@emeraldinsight.com 